\title{
Identification of implementable agricultural projects in the field of Ilam dam drinking water with the emphasis on sustainable development and environmental impacts.
}

\author{
Ali JAMSHIDI ${ }^{1}$, Karam KHALILI ${ }^{2}$, Esfandiar MOHAMMADI ${ }^{3}$ \\ ${ }^{1}$ Strategic Management M.A, Ilam Branch, Islamic Azad University, Ilam, Iran \\ ali.jamshidi.1384@gmail.com \\ ${ }^{2}$ Assistant Professor, Ilam Branch, Islamic Azad University, Ilam, Iran \\ Karam.Khalili@yahoo.com \\ ${ }^{3}$ Assistant Professor, Ilam Branch, Islamic Azad University, Ilam, Iran \\ Esfand1970@yahoo.com
}

\begin{abstract}
In the last decades, the lack of attention to the effects of development has led to large projects encounter serious problems due to underrate and inattention to the environment. So, in recent years, a movement has emerged towards the idea of strategic developmental impact assessment. The aim of the study is identifying and prioritizing implementable developmental projects in the area of Ilam dam water with the priority of assessing environmental impacts. The study is practical research .In regard of methodology, it is a descriptive- analytical research. Statistical sample includes two section .In qualitative section, experts familiar with the issues, problems and impacts of dam projects were used. In second section, knowledgeable experts in the field of dam catchment issues were used. Purposeful sampling was conducted in both sections. The data collection tool is questionnaire in form of open and closed questions. Data were analyzed using Lisrel tool and SPSS. Finally, 9 important factors were identified as project headlines as follows : 1.plant production projects 2: livestock production projects 3: water, soil and industry projects 4: Veterinary plans 5.forest, range land \& watershed plans 6.extention-operation plans 7.Economic organizations plans 8.Production cooperatives of agricultural Engineering services plans,9-Job opportunities in agriculture plans. Also, 82 headlines of developmental plan has been extracted to be assessing in the field of Ilam dam.
\end{abstract}

Keywords: employment, sustainable development, Ilam dam, implementable plans

\section{Introduction}

In the last decades, the lack of attention to the effects of development has led to large projects encounter serious problems due to underrate and inattention to the environment. So, in recent years, a movement has emerged towards the idea of strategic developmental impacts assessment. The aim of the study is to evaluate the environmental impact of projects implemented in the field of water, to ensure compliance with specified policies \& objectives in the programs and activities of the project in line with implementing social and environmental criteria, rules and regulations. Some people consider dam as effective way to drinking water supply and some believed that these executive and construction plans not only have not been successful in providing employment, but also the destruction of the country's watersheds and habitats has been followed. so, Environmental Impact 
assessment process is proposed with explaining the most Influential project activities on different aspects of the environment in search of appropriate prevention plans in order to reduce the negative Impacts of the project (Farhadian \& Kiani 2014,p.110).In general, water and water resources will significantly stimulate economic growth, create temporary and permanent employment opportunities, preventing rural migration and preventing inappropriate and often problematic jobs (Habibi\& Bastami \& Afshari1388,p.51).But, achieving the above regardless of environmental impact, undoubtedly provides problems . Actually, today due to population growth, creating employment plans in the field of drinking water catchment taking into account the protection of water resources and acknowledging the lack of water resource in the world including Iran and since the optimum use of lands and areas suitable for employment is inevitable and authorities would support them with the implementation of employment and generating plans, of course, with a view to the protection of water resources and without imposing pollution burden on them, it is obvious that the environmental impact projects should be considered and then Environmental Impact Assessment is one of the important ways to achieve sustainable development and one of the important tools of management and planning and decision-making.(Behzad, Shaibani, 1392,p.1). There is no doubt that the development and implementation of water projects in terms of raising the standard and quality of people's life is necessary and if we want to help people, water projects should be developed. Optimization usage of water resources can't be done unless three main principles, namely water consumption efficiency, equity in water distribution and maintain ecological and environmental balance, to be observed (Iranian Engineers club, 2000). Also in Ilam province, Ilam dam can be effective in employment in the province and particularly for the villagers, but without paying attention to environmental impacts, definitely sustainable and balanced development will not happen. So, the main subject of this research is to identifying and prioritizing implementable projects in the field of Ilam dam drinking water with the emphasis on environmental impacts.

\subsection{Human impact on environment}

Although humans constitute only a very small percentage of the earth's Biomass (weight or volume of organisms), but are species-dominated. At The beginning of the Pleistocene age, human was also influenced by Environmental factors as well as other beings. Since then, man has progressed and gradually was able to strongly change their physical environment (Kiani Haftleng, 1384). Actually, the relationship between man and the environment has completely changed alongside evolution of human and the technologies used by them. while human in the old days, especially early humans was influenced by environment, todays, this is the man who affected the environment by their behaviors and actions. Mutual and growing relationship between nature and organized society equipped with technical tools which interruptedly receives and uses the necessary resources from nature and returns the wastes resulting from production and life activities to it, is an undeniable fact. It is important to studying the "human-society and environment" system in regard of permanent and always sever interactions of material and energy among system factors which derived from permanent and growing social production, always more complex structure, and using raw material from the lands that are continually changing (Geramisovet al 1372). But the human impact on environment is result from his behavior and actions on the environment. Actions such as exploitation of natural resources, cutting trees, housing, factories constructing and etc in natural environments were led to changing the face of environments and if the trend continues, the reality is that human have been able to steadily increase the range of their interventions and impacts on the environment by developing sciences and 
technology to control it in order to achieve more profit and material well-being. Although, the technology is likely to have delayed the pollution crisis, but ultimately, the humane impact on the environment has increased. Technology not only has increased the utilization of resources but also has led to modern human affect environment by new ways compared with early hunter and foodcollecting human who used the stone and wood tools (Kiani Haftleng. 1384). By consequence of the technology development, the pace of changes in the environment has increased. This overshadowed man's relationship with his environment and led to changing his balanced relationship to a dominated relation and population growth, increase in production and competition among manufacturers have created a need for further exploitation of the natural environment. Actually, technologies of two recent centuries in various fields of humane knowledge caused environmental pollution (water, air and soil) and caused earth climate change (Ghaderi, 1383). As a result, further exploitation and production caused increasing pollution and destruction created by humans in environments and eventually became a critical stage which if you don't control it and protect the environment, sustainability crisis becomes more significant both in development and in Earth life and will lead to the occurrence of bitter reality, i.e. the destruction of life on earth by human. In the meantime, it is necessary that the foundation of the capitalist system consider as one of the most fundamental causes of negative environmental impacts. From another perspective, valuable judgments constituting the basis of human activities have direct effects on his interaction with the environment so that different ethical schools brought different results in environmental issues (Tohidnia1383).

Investigating preventive laws and regulations, including Environmental Impact Assessment (EIA) in Iran \& several industrial countries:

The pollution increasing which has affected air, soil and water in different ways and finally the degradation of normal human life as a result of impaired balance and fitness in environment has caused the governments, organizations and international bodies to formulating and implementing laws to prevent environmental pollution and degradation. Thus, binding environmental principals and laws gradually led to national and international development of environment and todays, environmental law and regulations is one of the most important tools and factors of environmental management and protection of its resources. Although, the implementation of environmental laws can't be expected to solve all environmental problems, because the role of the other factors such as people's awareness and institutionalization of this concept in culture and social behavior is very important and impressive, but, of course, preventing environmental pollution and regulating relations between human and environment will not be possible without binding legal rules. In recent century, after many years followed by the destruction of environment by human, it has been revealed that The development wouldn't be possible without planning. Thus, one of the key tools to achieving sustainable development goals is environmental Impact Assessment of developmental projects. Despite advances in Environmental Impact Assessment in the world, many countries including the Islamic Republic of Iran because of their scientific, administrative structure and scientific capacity need to support, strengthen and expand this knowledge and it should be noted that in Environmental Impact Assessment isn't a formal motion, rather, it is a management and binding plan to reform the ways of constructing and exploitation of developmental plans, and in this direction, if we can achieved to necessary performance, technology, strict enforcement of environmental standards, regulations and studies, valuable experience will emerge not only for the country but for the region and the world. In recent years, due to laws and regulations, preparing the assessment reports and drawing attention to this issue is required in many countries of the world, so that todays, there are few countries which are stranger with the Environmental Impact Assessment term. Islamic Republic 
of Iran also has acted to accept Environmental Impact Assessment in 1994 in the framework of legislation.

\subsection{Literature}

1) Shaibani,(1392), in an article titled Environmental Impact Assessment in irrigation and drainage networks, found that since the Environmental Impact Assessment is among the best ways which review and evaluated the effects of activities and parts of a project on the environment components and led to enabling planners on the situation of natural environment of the region by identifying the environment and understanding it's importance. So, in implementing developmental plans, these considerations must be considered alongside the dam (Shaibani, 1392).

2) Dizji \& Gholaminezhad (1390), in an article titled Economic growth, human development and water pollution caused by economic activities in the selected countries of the world, found that environmental degradation is accelerated economic growth. So, economic growth and human development is fueled by population and environmental degradation (Dizji \& Gholaminezhad 1390.p.17).

3) Ahmadi \& Hajinezhad (2010) in an article titled " Environmental degradation obstacle to sustainable development" found that sustainable development in the country will not happen without regard to environmental consideration and indicated that environmental assessment was respected in the implementation of all projects (Ahmadi \& Hajinezhad, 2010, p.129).

4) Karamooz, Elyasi \& Ahmadinia (1387), in an article titled "Economic analysis of the effects of demand management policies on water resources development projects", found that environmental assessment should always be considered as one of the pillars of resource development projects (Karamooz et. al 187, p.156). In 1986 November all fisheries were killed from Basel City, Switzerland, to the Netherlands coast as a result of spilling mercury and toxics such as pesticides in Rhine River .In recent years, sinking or grounding of large ocean-going oil tankers have resulted in damages to marine life. In 1983, about 120 million liters of contaminated materials was evacuated in the United States waters as a result of 11,000 pollution incidents. World Bank Report "World development Indicators" on the issue of water pollution in two section of organic water pollutants emission and the share of industry in emission of these materials, highlights: emissions of organic water pollutants was equal to $16 \% \mathrm{~kg}$ per day per worker in Iran in 1990 and by 2003 this figure remains stable .Interestingly, the emissions of pollutants has decreased from 1990 to 2003 in most countries including China, America, Japan, Russia, India, Germany and Brazil. In 2003, according to the World Bank, among all countries of the world, the highest level of water pollution was caused by the food and drink industry which it's maximum was recorded in Moldova country. Accordingly, 98 percent of total water pollution in this country was caused by the food and drink industry.

\section{Methodology}

The research method is qualitative-quantitative in nature. Coding is used in qualitative part and descriptive-correlation method is used in quantitative part. This study is an applied research in regard of its objective. Also, this study is a survey research because some of its data was collected by questionnaire. 


\subsection{Participants}

Due to the study nature, we have two statistical samples in this study. In qualitative part, community of experts and specialists familiar with the issue of water resources and developmental projects of agriculture, livestock and industry were selected, in quantitative part, sample was include 82 espicialists associated with the issue as reported in below table:

Table 1: Sample includes 82 specialists

\begin{tabular}{|c|l|c|}
\hline Row & Organization & Number \\
\hline 1 & University Professors & 5 \\
\hline 2 & Industry, Trade \& Mining Department & 8 \\
\hline 3 & Water and sewage Department & 25 \\
\hline 4 & Environment Department & 13 \\
\hline 5 & Regional water and Health Department & 30 \\
\hline 6 & Governor General Office & 2 \\
\hline Total & & 82 \\
\hline
\end{tabular}

\subsection{Sampling}

In qualitative part, 8 people were selected based on expertise in the field of qualitative and quantitative protection of the province water resources (members of the province water resources protection committee), Sampling was targeted in quantitative part. In this part 82 people were selected due to the limited number of experts in the related field.

\subsection{Data analysis}

Data collected and classified by questionnaires was used as the primary source for new information about the studied issue. In this study, Grounded theory Technique was used to analyzing data in qualitative part. In quantitative part, first frequency distribution tables and charts were used to describing data and then, Structural Equations Tests were used to examining the research questions and hypotheses of quantitative section.

\subsection{Inferential findings:}

\section{Variables Normality test:}

In this stage, first data normality examined using Kolmogorov- Smirnov Test, then in order to test each hypotheses, its related test was used. For this purpose, hypotheses related to this section include: H0: Data distribution is normal.

H1: Data distribution isn't normal.

Above hypothesis was investigated using Kolmogorov-Smirnov Test (KS Test) for research variables which it's results is shown in the following table.

Above hypothesis for research's variables was studied through Kolmogorov -Smirnoff test (KS test) whose results have been shown in below table: 
Table 2: Normality test of research's variables

\begin{tabular}{|c|c|c|c|}
\hline Plans & $\begin{array}{c}\text { Number of } \\
\text { items }\end{array}$ & $\begin{array}{c}\text { Significance } \\
\text { level }\end{array}$ & results \\
\hline Plant production affairs & 9 & 0.54 & $\begin{array}{c}\text { data distribution is normal } \\
\text { data distribution is normal }\end{array}$ \\
\hline Livestock production affairs & 3 & 0.66 & data distribution is normal \\
\hline Soil, water and industry plans & 21 & 0.81 & data distribution is normal \\
\hline Veterinary & 8 & 0.58 & data distribution is normal \\
\hline Jungle, rangeland and watershed & 10 & 0.34 & data distribution is normal \\
\hline Promotion and exploitation & 5 & 0.71 & data distribution is normal \\
\hline Economic organizations & 13 & 0.38 & data distribution is normal \\
\hline Agricultural engineering service production & 8 & 0.76 & data distribution is normal \\
\hline cooperatives & 5 & 0.32 & data distribution is normal \\
\hline
\end{tabular}

Hypotheses confirmation or rejection in human science is normally stated with 95 percent of confidence. On the other hand, significance level which is obtained through software SPSS indicates error rate that may be committed in rejecting hypothesis H0. Therefore, if this value is more than (1-0.95) 0.5, hypothesis $\mathrm{H} 0$ cannot be easily rejected. As it is observed in above table, significance level of each variable is more than 0.05 , so hypothesis H0 cannot be rejected with 95 percent of confidence. In the other word, hypothesis H0 which indicates data normality is confirmed regarding all the variables.

\section{Confirmative factorial analysis of research's variables by using structural equations}

\subsection{Confirmative factorial analysis of plants production affairs plans}

9 number of suggested plans in classification of plants production affairs plans were identified that mean and confirmative factorial analysis have been used for applicability, importance and prioritizing these plans whose results have been reported in continue. 


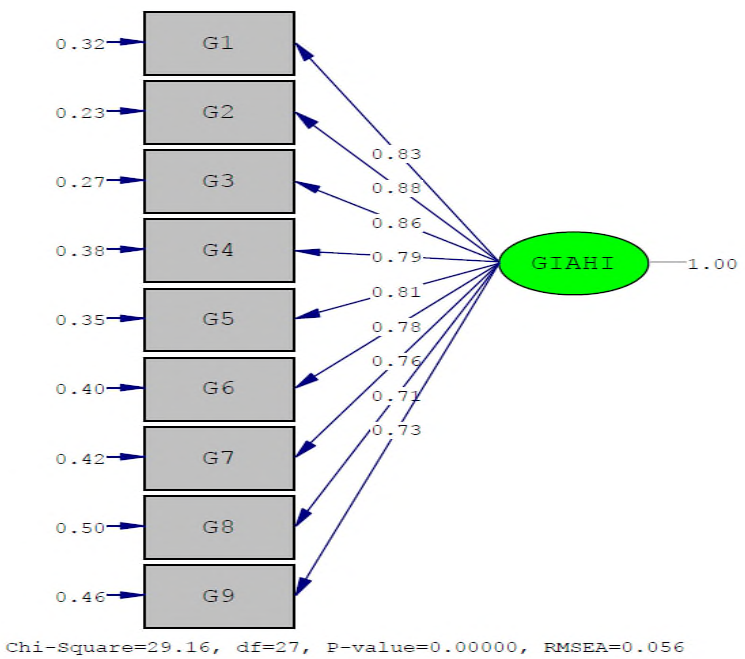

Diagram 1: Confirmative factorial analysis of plant production affairs plans at standard estimation status

Table 2: The results of confirmative factorial analysis

\begin{tabular}{|c|c|c|c|c|c|c|}
\hline $\begin{array}{c}\text { Classification } \\
\text { of plans }\end{array}$ & Identified plans & mean & $\begin{array}{l}\text { factorial } \\
\text { load }\end{array}$ & $\begin{array}{c}\text { Significance } \\
\text { number }\end{array}$ & result & prioritizing \\
\hline \multirow[t]{9}{*}{$\begin{array}{l}\text { Plant } \\
\text { production } \\
\text { affairs }\end{array}$} & $\begin{array}{c}\text { Construction and } \\
\text { development of irrigated } \\
\text { and non-irrigated gardens }\end{array}$ & 3.29 & 0.83 & 9.01 & applicable & 4 \\
\hline & $\begin{array}{l}\text { Modification, replacement } \\
\text { and renovation of gardens }\end{array}$ & 3.52 & 0.88 & 9.95 & applicable & 1 \\
\hline & $\begin{array}{l}\text { Production of certified } \\
\text { plants }\end{array}$ & 3.28 & 0.86 & 9.52 & applicable & 5 \\
\hline & $\begin{array}{c}\text { Construction of greenhouses } \\
\text { producing flower and } \\
\text { vegetable }\end{array}$ & 3.12 & 0.79 & 8.35 & applicable & 7 \\
\hline & $\begin{array}{l}\text { Reform, modernization and } \\
\text { equipping of greenhouses }\end{array}$ & 3.34 & 0.81 & 8.66 & applicable & 3 \\
\hline & $\begin{array}{l}\text { Medicinal plants production } \\
\text { and collection and plants } \\
\text { cultivation }\end{array}$ & 3.48 & 0.78 & 8.20 & applicable & 2 \\
\hline & $\begin{array}{l}\text { Establishment, equipment } \\
\text { and development of } \\
\text { agricultural mechanization } \\
\text { units }\end{array}$ & 3.18 & 0.76 & 7.99 & applicable & 6 \\
\hline & $\begin{array}{l}\text { Development of rice } \\
\text { transplanting bank and rice } \\
\text { hybrid seed production }\end{array}$ & 3.03 & 0.71 & 7.19 & applicable & 9 \\
\hline & $\begin{array}{c}\text { Development of } \\
\text { transplanting and vegetable } \\
\text { and vegetable hybrid seed } \\
\text { production }\end{array}$ & 3.11 & 0.73 & 7.56 & applicable & 8 \\
\hline
\end{tabular}

The results of confirmative factorial analysis show that all the factorial loads and significance coefficients had been confirmed, its measurement model is appropriate and 
the entire model's numbers and parameters are significant. According to this fact that average of all plans are higher than 3 and all the factorial loads and significance coefficients have been confirmed, so identified plans in the field of vegetable production affair are all applicable. Prioritizing plans has been done according to average upon which three plans including modification, replacement and renovation of gardens, Medicinal plants production and collection and plants cultivation and reform, modernization and equipping of greenhouses are respectively placed at first, second and third rank of priority.

\subsection{Confirmative factorial analysis of livestock production affairs plans}

3 number of suggested plans in classification of livestock production affairs plans were identified that mean and confirmative factorial analysis have been used for applicability, importance and prioritizing these plans whose results have been reported in continue.

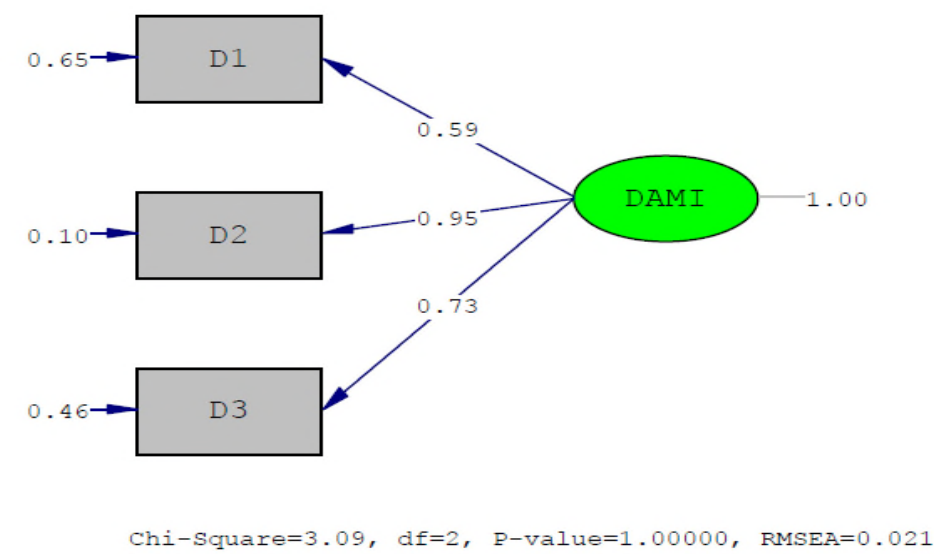

Diagram 2: Confirmative factorial analysis of veterinary production affairs plans at standard estimation status

Table 3: The results of confirmative factorial analysis

\begin{tabular}{|c|c|c|c|c|c|c|}
\hline $\begin{array}{c}\text { Classification of } \\
\text { plans }\end{array}$ & Identified plans & mean & $\begin{array}{c}\text { factorial } \\
\text { load }\end{array}$ & $\begin{array}{l}\text { Significance } \\
\text { number }\end{array}$ & Result & prioritizing \\
\hline \multirow[t]{2}{*}{$\begin{array}{c}\text { Livestock } \\
\text { production affair }\end{array}$} & $\begin{array}{l}\text { Establishment of units for queen } \\
\text { beekeeping }\end{array}$ & 3.24 & 0.59 & 9.57 & applicable & 3 \\
\hline & $\begin{array}{l}\text { Construction of convertible and } \\
\text { complementary industries which are } \\
\text { subdivision of vegetable production } \\
\text { including storage and freezing different } \\
\text { kinds of beans, vegetable, citrus and } \\
\text { agricultural crops, different types of fruit } \\
\text { juice and refrigerating chambers }\end{array}$ & 3.40 & 0.73 & 11.92 & applicable & 2 \\
\hline
\end{tabular}

The results of confirmative factorial analysis show that all the factorial loads and significance coefficients had been confirmed, its measurement model is appropriate and 
the entire model's numbers and parameters are significant. According to this fact that average of all plans are higher than 3 and all the factorial loads and significance coefficients have been confirmed, so identified plans in the field of veterinary production affair are all applicable. Prioritizing plans has been done according to average upon which three plans including establishment of units for breeding silkworm and mobile milk collection centers, construction of convertible and complementary industries which are subdivision of vegetable production including storage and freezing different kinds of beans, vegetable, citrus and agricultural crops, different types of fruit juice and refrigerating chambers and establishment of units for queen beekeeping are respectively placed at first, second and third rank of priority.

\subsection{Confirmative factorial analysis of soil, water and industry plans}

21 number of suggested plans in classification of soil, water and industry plans were identified that mean and confirmative factorial analysis have been used for applicability, importance and prioritizing these plans whose results have been reported in continue.

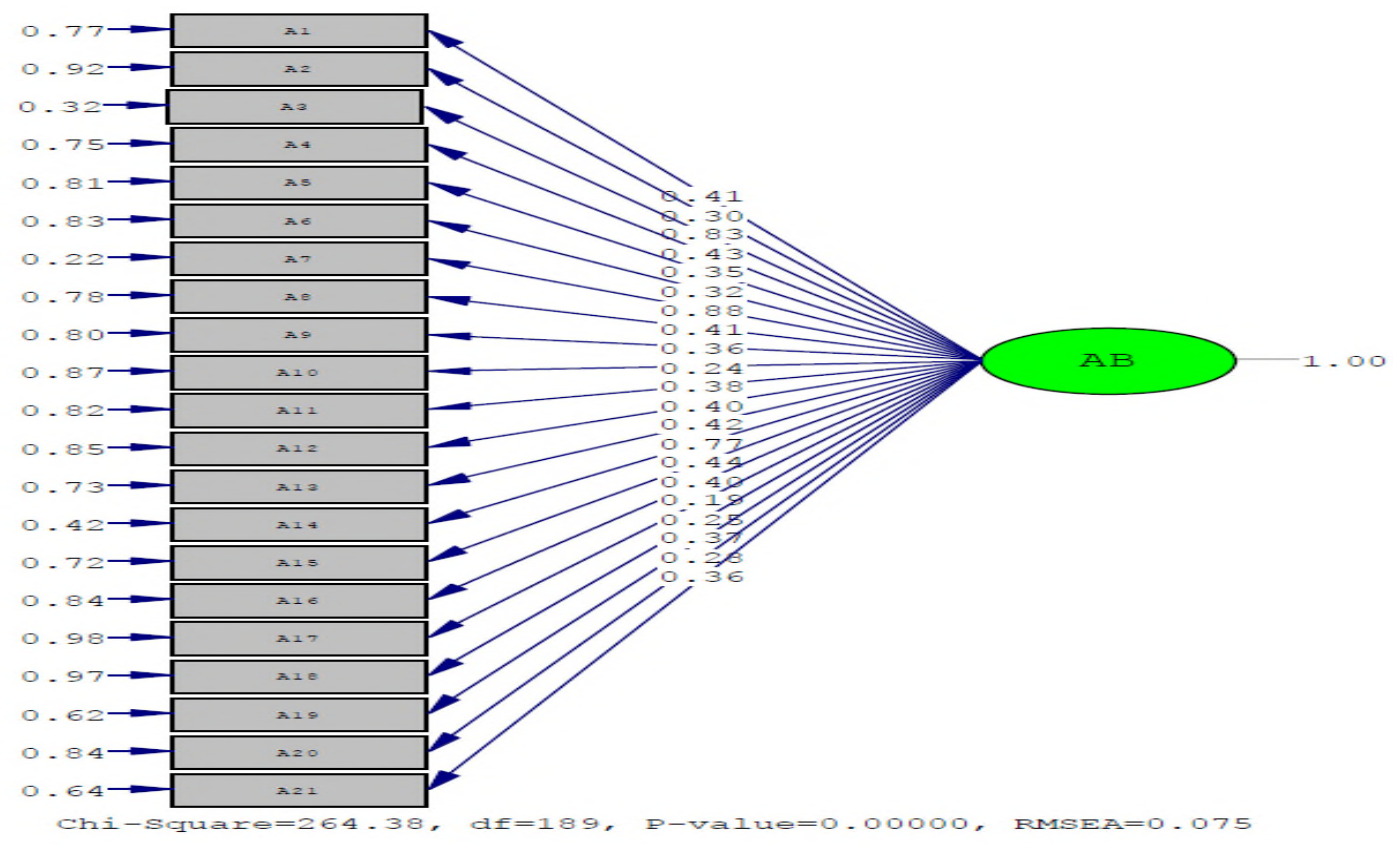

Diagram 3: Confirmative factorial analysis of soil, water and industry plans at standard estimation status 
Table 4: The results of confirmative factorial analysis

\begin{tabular}{|c|c|c|c|c|c|c|}
\hline $\begin{array}{l}\text { Classifi } \\
\text { cation } \\
\text { of plans }\end{array}$ & Identified plans & mean & $\begin{array}{c}\text { Factorial } \\
\text { load }\end{array}$ & $\begin{array}{l}\text { Significance } \\
\text { number }\end{array}$ & result & $\begin{array}{c}\text { prioritizi } \\
\text { ng }\end{array}$ \\
\hline \multirow{21}{*}{ 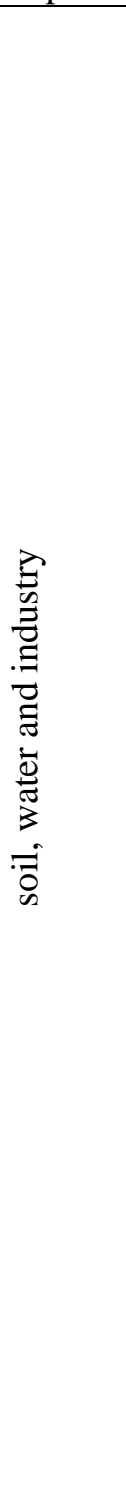 } & Dabbaqi and Slumber's plan & 1.58 & 0.41 & 1.58 & Non-applicable & \\
\hline & $\begin{array}{l}\text { Non-natural and with essence } \\
\text { beverage and fruit juice industry }\end{array}$ & 1.86 & 0.30 & 1.23 & Non-applicable & \\
\hline & Wood products industry & 3.22 & 0.83 & 9.21 & applicable & 2 \\
\hline & Gas station & 2.25 & 0.43 & 1.64 & Non-applicable & \\
\hline & Pitch and asphalt industry & 1.78 & 0.35 & 1.21 & Non-applicable & \\
\hline & Metal melting & 1.81 & 0.32 & 1.58 & Non-applicable & \\
\hline & $\begin{array}{c}\text { Manufacture of food products } \\
\text { including cookies and pastry industry }\end{array}$ & 3.38 & 0.88 & 9.96 & applicable & 1 \\
\hline & $\begin{array}{l}\text { Poultry and livestock industrial } \\
\text { slaughterhouse }\end{array}$ & 1.53 & 0.41 & 1.56 & Non-applicable & \\
\hline & $\begin{array}{l}\text { Packing meat and production of meat } \\
\text { products }\end{array}$ & 2.32 & 0.36 & 1.38 & Non-applicable & \\
\hline & $\begin{array}{l}\text { Compost production of municipal } \\
\text { waste plan }\end{array}$ & 1.84 & 0.24 & 1.01 & Non-applicable & \\
\hline & $\begin{array}{c}\text { Compost production of livestock } \\
\text { dung }\end{array}$ & 2.01 & 0.38 & 1.32 & Non-applicable & \\
\hline & Industrial oil Refining plan & 2.01 & 0.40 & 1.55 & Non-applicable & \\
\hline & Production and refining of edible oils & 2.15 & 0.42 & 1.69 & Non-applicable & \\
\hline & $\begin{array}{l}\text { Production of bricks and ready } \\
\text { concrete products plan }\end{array}$ & 3.08 & 0.77 & 8.16 & applicable & \\
\hline & $\begin{array}{l}\text { Production of packed building } \\
\text { plaster and lime plan }\end{array}$ & 2.20 & 0.44 & 1.66 & Non-applicable & \\
\hline & $\begin{array}{c}\text { Plastic and rubber production } \\
\text { industry }\end{array}$ & 2.00 & 0.40 & 1.57 & Non-applicable & \\
\hline & Human medicine industry & 2.24 & 0.19 & 1.09 & Non-applicable & \\
\hline & $\begin{array}{l}\text { Animal and aquatic medicine } \\
\text { industry }\end{array}$ & 2.19 & 0.25 & 1.14 & Non-applicable & \\
\hline & $\begin{array}{l}\text { Automotive products production } \\
\text { industry }\end{array}$ & 2.15 & 0.37 & 1.28 & Non-applicable & \\
\hline & Production of car tires industry & 1.81 & 0.28 & 1.32 & Non-applicable & \\
\hline & $\begin{array}{c}\text { Paints and chemicals production } \\
\text { industry }\end{array}$ & 1.56 & 0.36 & 1.39 & Non-applicable & \\
\hline
\end{tabular}

The results of confirmative factorial analysis show that just three items of factorial loads and significance coefficients had been confirmed. According to this fact that average of all plans are higher than 3 and all the factorial loads and significance coefficients have been confirmed, so among identified plans in the field of soil, water and industry, just three plans including soil, water and industry are applicable. Prioritizing plans has been done according to average upon which three plans including manufacture of food products including cookies and pastry industry, wood products industry and production of bricks and ready concrete products plan are respectively placed at first, second and third rank of priority. 


\subsection{Confirmative factorial analysis of veterinary plans}

8 number of suggested plans in classification of veterinary plans were identified that mean and confirmative factorial analysis have been used for applicability, importance and prioritizing these plans whose results have been reported in continue.

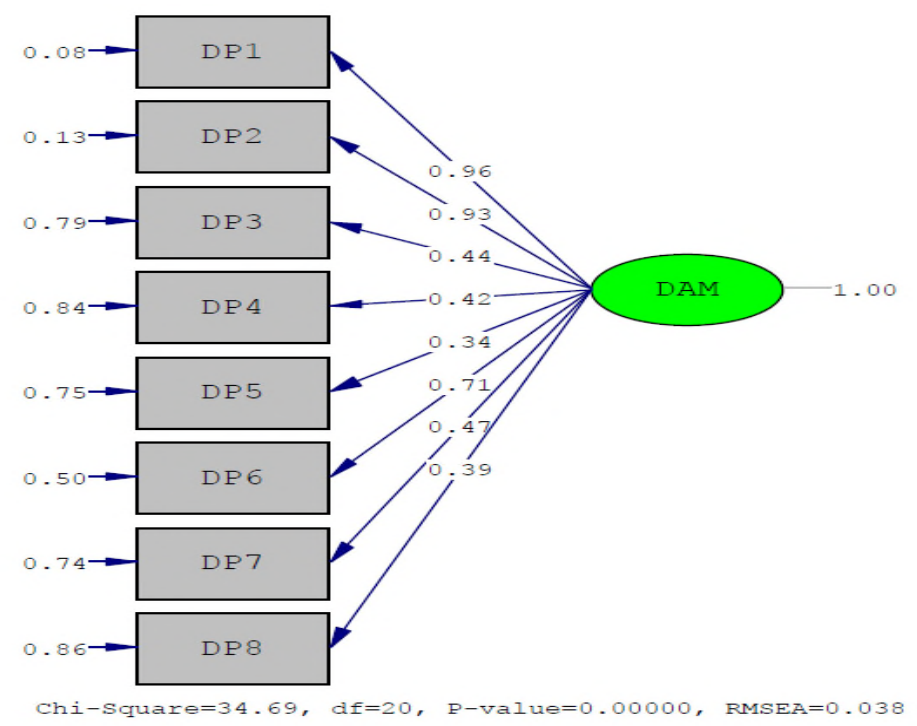

Diagram 4: confirmative factorial analysis of veterinary plans at standard estimation status

Table 5: The results of confirmative factorial analysis

\begin{tabular}{|c|c|c|c|c|c|c|}
\hline $\begin{array}{c}\text { Classification } \\
\text { of plans }\end{array}$ & Identified plans & mean & $\begin{array}{l}\text { Factorial } \\
\text { load }\end{array}$ & $\begin{array}{c}\text { Significa } \\
\text { nce } \\
\text { number }\end{array}$ & results & $\begin{array}{c}\text { prioritizi } \\
\text { ng }\end{array}$ \\
\hline \multirow[t]{8}{*}{ Veterinary } & $\begin{array}{l}\text { Establishment of convertible } \\
\text { and complementary industry } \\
\text { subdivision of livestock } \\
\text { production, fridge, Processing } \\
\text { and packaging of meat, poultry } \\
\text { and dairy products }\end{array}$ & 3.69 & 0.96 & 10.64 & applicable & 1 \\
\hline & $\begin{array}{l}\text { Establishment of convertible } \\
\text { and complementary industry } \\
\text { subdivision of fishery including } \\
\text { processing, freezing and } \\
\text { packing different types of fish, } \\
\text { shrimp and conserves }\end{array}$ & 3.48 & 0.93 & 10.41 & applicable & 2 \\
\hline & Less than 25 head of cattle plan & 3.22 & 0.44 & 1.77 & Non-applicable & \\
\hline & $\begin{array}{c}\text { more than } 25 \text { head of cattle } \\
\text { plan }\end{array}$ & 2.25 & 0.42 & 1.92 & Non-applicable & \\
\hline & $\begin{array}{l}\text { Egg-laying poultry plan of ten } \\
\text { thousand piece and more }\end{array}$ & 1.78 & 0.34 & 1.31 & Non-applicable & \\
\hline & $\begin{array}{l}\text { Breeding hydrothermal and } \\
\text { cold-water fish }\end{array}$ & 3.26 & 0.61 & 8.33 & applicable & 3 \\
\hline & $\begin{array}{l}\text { Hundred head of industrial } \\
\text { cattle plan }\end{array}$ & 3.38 & 0.47 & 1.94 & Non-applicable & \\
\hline & Two-Hundred head of & 1.53 & 0.39 & 1.65 & Non-applicable & \\
\hline
\end{tabular}


The results of confirmative factorial analysis show that just three items of factorial loads and significance coefficients had been confirmed. According to this fact that average of all plans are higher than 3 and all the factorial loads and significance coefficients have been confirmed, so among identified plans in the field of veterinary, just three plans of veterinary are applicable. Prioritizing plans has been done according to average upon which three plans including establishment of convertible and complementary industry subdivision of livestock production, fridge, Processing and packaging of meat, poultry and dairy products, establishment of convertible and complementary industry subdivision of fishery including processing, freezing and packing different types of fish, shrimp and conserves a breeding hydrothermal and cold-water fish are respectively placed at first, second and third rank of priority.

\subsection{Confirmative factorial analysis of jungle, rangeland and watershed}

10 number of suggested plans in classification of jungle, rangeland and watershed were identified that mean and confirmative factorial analysis have been used for applicability, importance and prioritizing these plans whose results have been reported in continue.

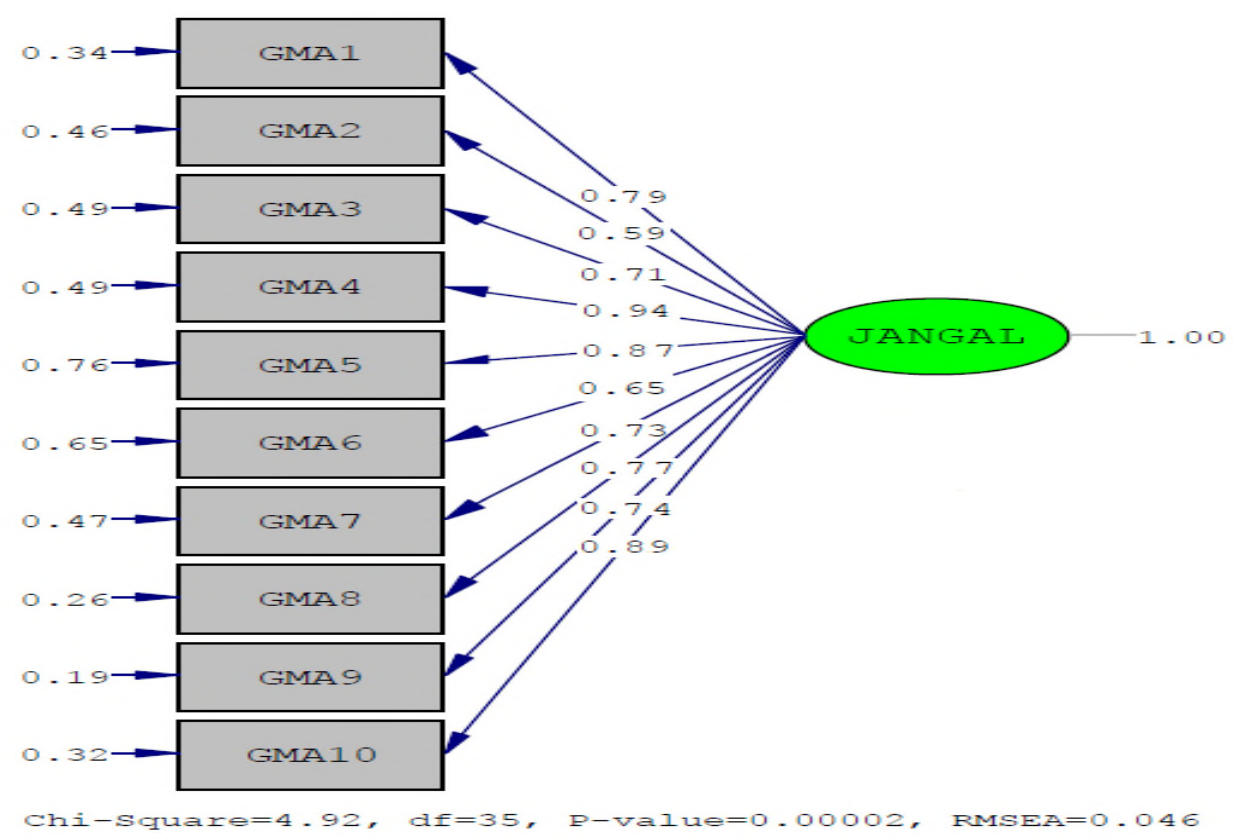

Diagram 5: Confirmative factorial analysis of jungle, rangeland and watershed plans at standard estimation status 
Table 6: the results of confirmative factorial analysis

\begin{tabular}{|c|c|c|c|c|c|c|}
\hline $\begin{array}{l}\text { Classificati } \\
\text { on of plans }\end{array}$ & Identified plans & mean & $\begin{array}{c}\text { Factorial } \\
\text { load }\end{array}$ & $\begin{array}{l}\text { Significan } \\
\text { ce number }\end{array}$ & result & $\begin{array}{c}\text { prioritizin } \\
\mathrm{g}\end{array}$ \\
\hline \multirow{10}{*}{ 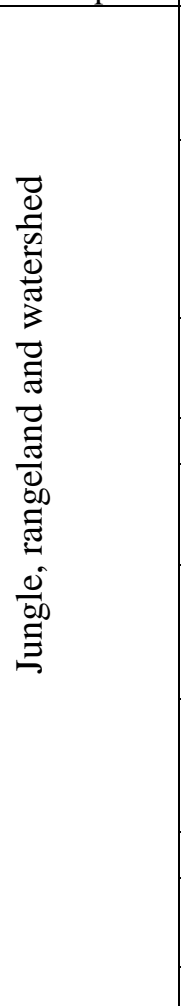 } & $\begin{array}{l}\text { Creating and launching a consulting } \\
\text { service companies, Agricultural } \\
\text { engineering and technology companies }\end{array}$ & 3.49 & 0.79 & 11.15 & applicable & 5 \\
\hline & $\begin{array}{l}\text { Creating mechanization services } \\
\text { companies an different kinds of medical } \\
\text { plant and veterinary clinics, water, soil } \\
\text { and plants protection }\end{array}$ & 3.01 & 0.59 & 9.23 & applicable & 10 \\
\hline & $\begin{array}{l}\text { Cooperatives produce transplants of non- } \\
\text { fruit bearing trees (tree nursery) }\end{array}$ & 3.57 & 0.71 & 11.42 & applicable & 4 \\
\hline & Create forestry projects & 4.03 & 094 & 12.34 & applicable & 1 \\
\hline & $\begin{array}{l}\text { Running watershed operations in } \\
\text { exceptions lands }\end{array}$ & 3.68 & 0.87 & 11.67 & applicable & 3 \\
\hline & $\begin{array}{c}\text { Design and development fruit groves and } \\
\text { greenhouse products and creating tree } \\
\text { nursery }\end{array}$ & 3.03 & 0.65 & 9.76 & applicable & 9 \\
\hline & $\begin{array}{l}\text { Providing mechanization(performing all } \\
\text { the stages of planting, storage and } \\
\text { harvesting of product) }\end{array}$ & 3.27 & 0.73 & 10.12 & applicable & 8 \\
\hline & Small plans of household agriculture & 3.42 & 0.77 & 10.57 & applicable & 6 \\
\hline & $\begin{array}{c}\text { Small plans of agricultural convertible } \\
\text { industry }\end{array}$ & 3.38 & 0.74 & 10.43 & applicable & 7 \\
\hline & Employment projects for rural women & 3.78 & 0.89 & 12.27 & applicable & 2 \\
\hline
\end{tabular}

The results of confirmative factorial analysis show that just three items of factorial loads and significance coefficients had been confirmed. According to this fact that average of all plans are higher than 3 and all the factorial loads and significance coefficients have been confirmed, so among identified plans in the field of jungle, rangeland and watershed, all 8 plans are applicable. Prioritizing plans has been done according to average upon which three plans including forestry projects, Employment projects for rural women and Running watershed operations in exceptions lands are respectively placed at first, second and third rank of priority.

\subsection{Confirmative factorial analysis of promotion and exploitation plans}

5 number of suggested plans in classification of promotion and exploitation plans were identified that mean and confirmative factorial analyses have been used for applicability, importance and prioritizing these plans whose results have been reported in continue. 


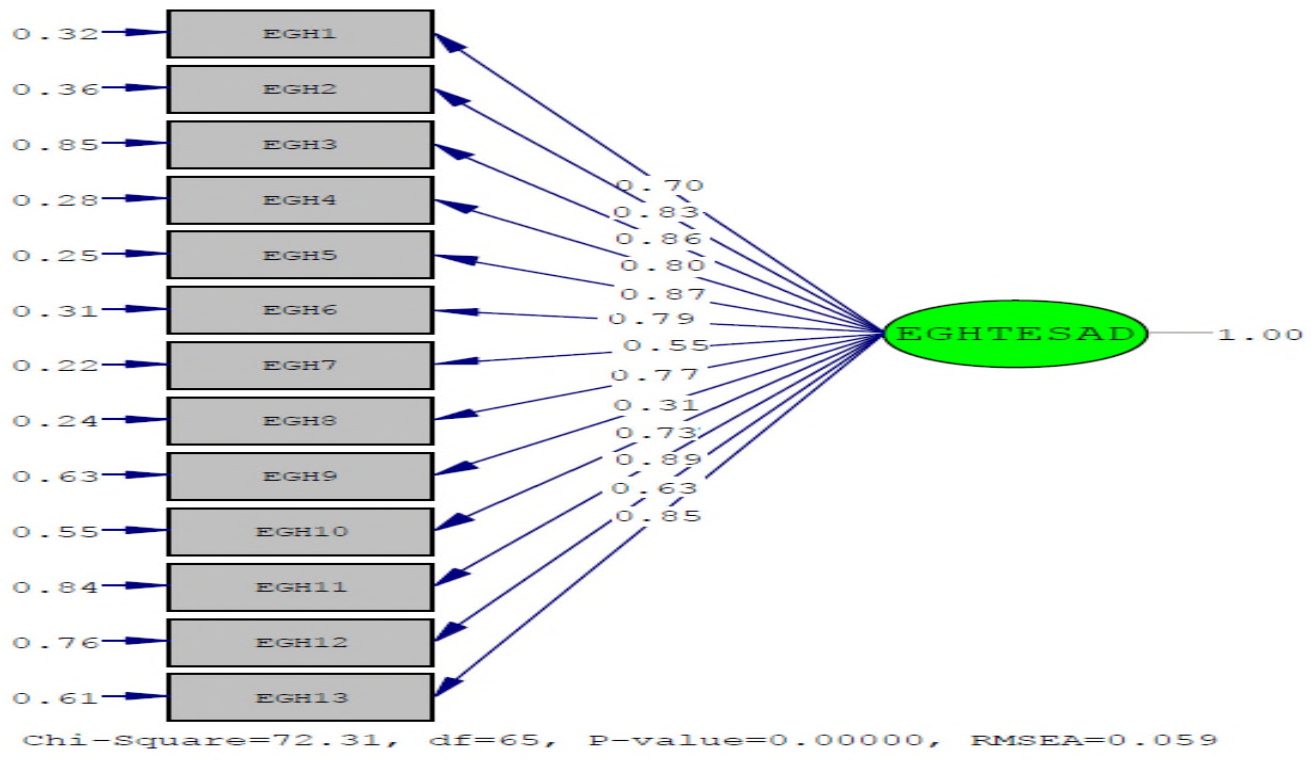

Diagram 6: Confirmative factorial analysis of jungle, rangeland and watershed plans at standard estimation status

Table 7: The results of confirmative factorial analysis

\begin{tabular}{|c|c|c|c|c|c|c|}
\hline $\begin{array}{c}\text { Classification } \\
\text { of plans }\end{array}$ & Identified plans & mean & $\begin{array}{c}\text { Factorial } \\
\text { load }\end{array}$ & $\begin{array}{c}\text { Significance } \\
\text { number }\end{array}$ & result & prioritizing \\
\hline \multirow{5}{*}{ 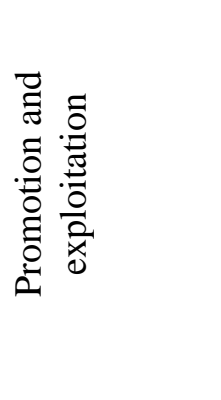 } & $\begin{array}{l}\text { Cooperative produce transplant of non- } \\
\text { fruit bearing trees }\end{array}$ & 3.00 & 0.56 & 8.54 & applicable & 5 \\
\hline & Mechanized brick production plan & 3.73 & 0.92 & 12.24 & applicable & 2 \\
\hline & $\begin{array}{l}\text { Medicinal and industrial plants } \\
\text { development plan }\end{array}$ & 3.75 & 0.93 & 12.42 & applicable & 1 \\
\hline & $\begin{array}{l}\text { Forest and grassland transplant } \\
\text { production plan }\end{array}$ & 3.28 & 0.68 & 9.84 & applicable & 4 \\
\hline & $\begin{array}{c}\text { vegetable and summer crops production } \\
\text { cooperatives }\end{array}$ & 3.35 & 0.70 & 9.98 & applicable & 3 \\
\hline
\end{tabular}

The results of confirmative factorial analysis show that just three items of factorial loads and significance coefficients had been confirmed. According to this fact that average of all plans are higher than 3 and all the factorial loads and significance coefficients have been confirmed, so among identified plans in the field of jungle, rangeland and watershed, all 8 plans are applicable. Prioritizing plans has been done according to average upon which three plans including medicinal and industrial plants development plan forestry, mechanized brick production plan and Cooperatives producing vegetable are respectively placed at first, second and third rank of priority.

\subsection{Confirmative factorial analysis of economic organizations plans}

5 number of suggested plans in classification of promotion and exploitation plans were identified that mean and confirmative factorial analyses have been used for applicability, importance and prioritizing these plans whose results have been reported in continue. 


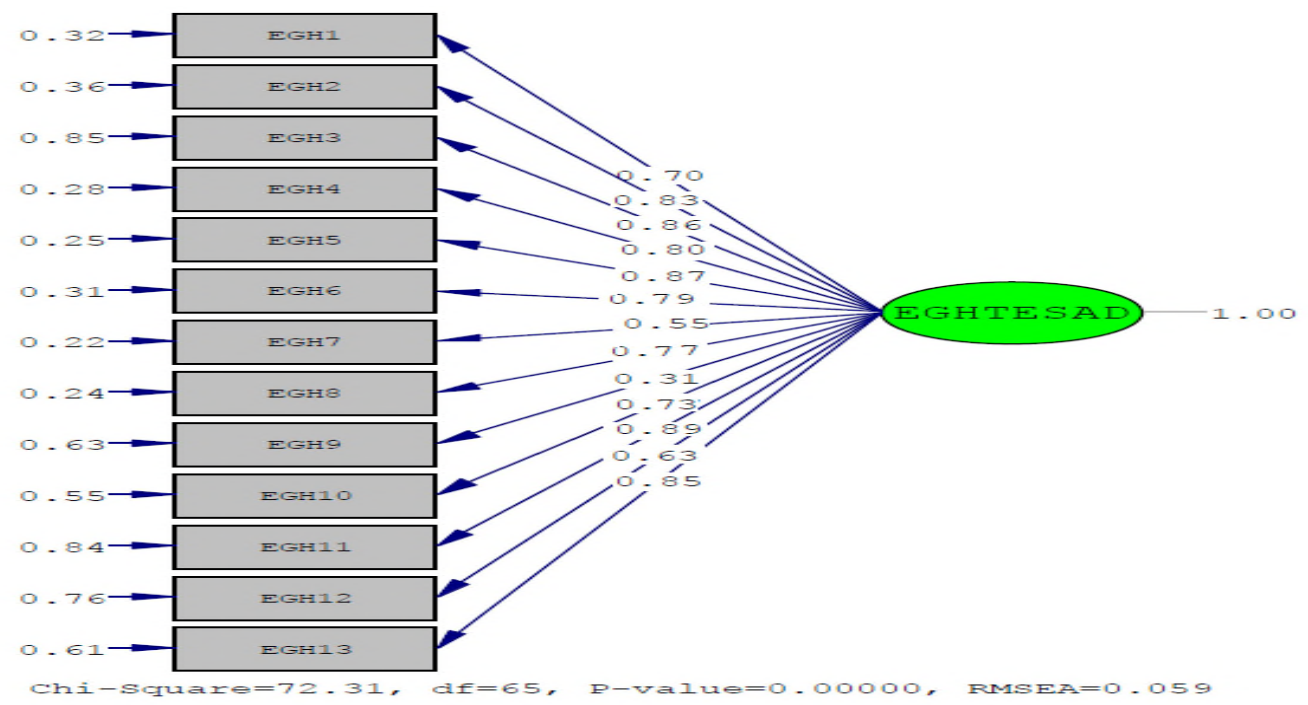

Diagram 7: Confirmative factorial analysis of economic organizations plans at standard estimation status

Table 8: the results of confirmative factorial analysis

\begin{tabular}{|c|c|c|c|c|c|c|}
\hline $\begin{array}{l}\text { Classification of } \\
\text { plans }\end{array}$ & Identified plans & mean & $\begin{array}{l}\text { Factorial } \\
\text { load }\end{array}$ & $\begin{array}{l}\text { Significance } \\
\text { number }\end{array}$ & result & prioritizing \\
\hline \multirow{13}{*}{ 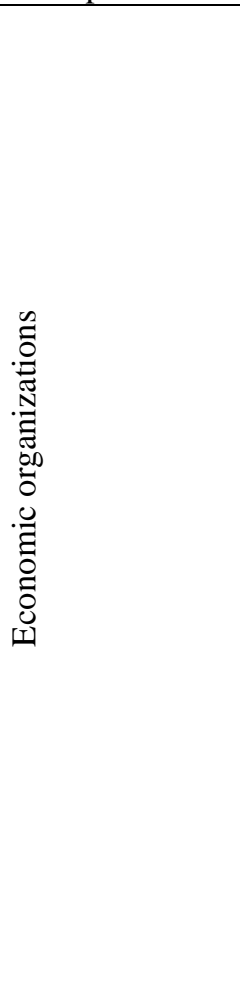 } & $\begin{array}{l}\text { Cooperatives of agricultural inputs and } \\
\text { machinery preparation and distribution service }\end{array}$ & 3.09 & 0.70 & 9.92 & applicable & \\
\hline & $\begin{array}{l}\text { preparation and distribution cooperatives of } \\
\text { different kinds of transplant and plant }\end{array}$ & 3.33 & 0.83 & 10.72 & applicable & \\
\hline & $\begin{array}{c}\text { Mechanization service cooperatives in order to } \\
\text { offer service to farmers }\end{array}$ & 3.54 & 0.86 & 11.21 & applicable & \\
\hline & $\begin{array}{l}\text { Cereals production cooperative (wheat and } \\
\text { barley) }\end{array}$ & 3.30 & 0.80 & 10.33 & applicable & \\
\hline & $\begin{array}{l}\text { fruit-trees and non- fruit bearing trees production } \\
\text { and distribution cooperatives }\end{array}$ & 3.63 & 0.89 & 11.38 & applicable & \\
\hline & $\begin{array}{l}\text { Cooperatives producing greenhouse summer } \\
\text { crops (Construction of greenhouses) }\end{array}$ & 3.21 & 0.79 & 10.63 & applicable & \\
\hline & $\begin{array}{l}\text { Cooperatives establishing and distributing } \\
\text { agricultural service institutions }\end{array}$ & 3.00 & 0.55 & 9.77 & applicable & \\
\hline & $\begin{array}{l}\text { dependent industry cooperatives of agricultural } \\
\text { products }\end{array}$ & 3.20 & 0.77 & 10.57 & applicable & \\
\hline & Direct machine supply market cooperatives & 2.68 & 0.31 & 1.69 & $\begin{array}{l}\text { Non- } \\
\text { applicable }\end{array}$ & \\
\hline & Silkworm production and breeding cooperatives & 3.17 & 0.73 & 10.37 & applicable & \\
\hline & $\begin{array}{l}\text { Honey production cooperatives(beekeepers } \\
\text { cooperative) }\end{array}$ & 3.74 & 0.89 & 11.88 & applicable & \\
\hline & Milk collection centers cooperatives & 3.04 & 0.63 & 9.83 & applicable & \\
\hline & $\begin{array}{l}\text { Rangeland and forestry's byproducts production } \\
\text { cooperatives }\end{array}$ & 3.53 & 0.85 & 10.94 & applicable & \\
\hline
\end{tabular}

The results of confirmative factorial analysis show that just three items of factorial loads and significance coefficients had been confirmed. According to this fact that average of 12 plans from 13 ones are higher than 3 and all the factorial loads and significance coefficients have been confirmed, so among identified plans in the field of economic 
organizations, all 12 plans are applicable. Prioritizing plans has been done according to average upon which three plans including Honey production cooperatives(beekeepers cooperative), fruit-trees and non- fruit bearing trees production and distribution cooperatives and Mechanization service cooperatives in order to offer service to farmers are respectively placed at first, second and third rank of priority.

\subsection{Confirmative factorial analysis of productive cooperatives plans}

8 number of suggested plans in classification of productive cooperatives plans were identified that mean and confirmative factorial analyses have been used for applicability, importance and prioritizing these plans whose results have been reported in continue.

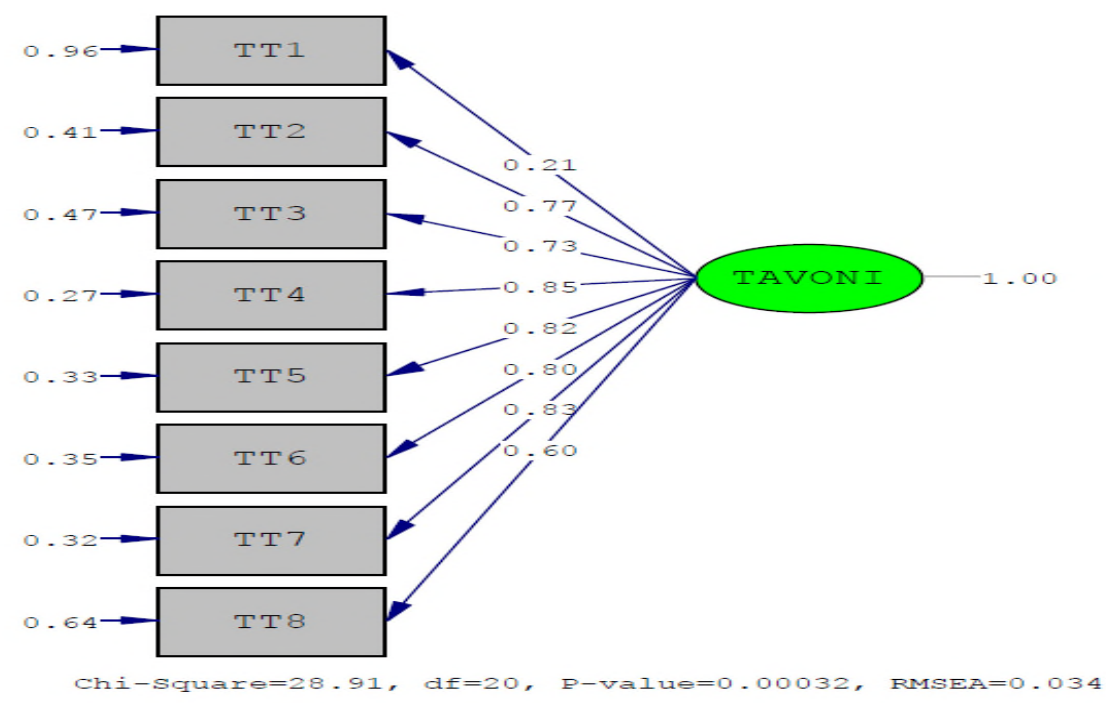

Diagram 8: Confirmative factorial analysis of production cooperatives plans at standard estimation status

Table 9: The results of confirmative factorial analysis

\begin{tabular}{|c|c|c|c|c|c|c|}
\hline $\begin{array}{c}\text { Classification of } \\
\text { plans }\end{array}$ & Identified plans & Mean & $\begin{array}{l}\text { Factorial } \\
\text { load }\end{array}$ & $\begin{array}{l}\text { Significance } \\
\text { number }\end{array}$ & Result & prioritizing \\
\hline \multirow{8}{*}{ 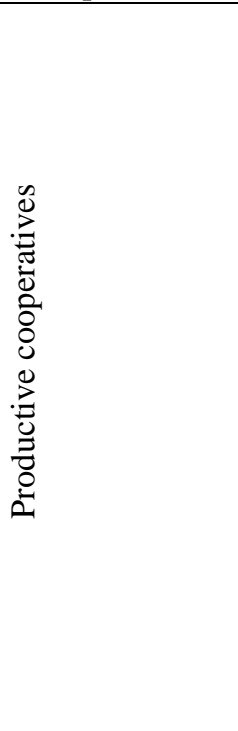 } & fight against pests and plant diseases & 2.36 & 0.21 & 1.06 & $\begin{array}{l}\text { Non- } \\
\text { applicable }\end{array}$ & 8 \\
\hline & $\begin{array}{c}\text { Repair and maintenance of agricultural } \\
\text { machinery and tools (machinery training and } \\
\text { maintenance) }\end{array}$ & 3.03 & 0.77 & 9.62 & Applicable & 7 \\
\hline & $\begin{array}{c}\text { Study, design and implementation of pressurized } \\
\text { irrigation systems }\end{array}$ & 3.69 & 0.73 & 11.45 & applicable & 1 \\
\hline & $\begin{array}{c}\text { Hydrology and geology laboratories } \\
\text { establishment }\end{array}$ & 3.63 & 0.85 & 10.87 & Applicable & 2 \\
\hline & $\begin{array}{c}\text { Establishing laboratories for checking pests and } \\
\text { plants diseases }\end{array}$ & 3.10 & 0.82 & 9.98 & Applicable & 6 \\
\hline & $\begin{array}{l}\text { modified seed transplants Production and } \\
\text { distribution required for region }\end{array}$ & 3.35 & 0.80 & 10.63 & Applicable & 4 \\
\hline & $\begin{array}{l}\text { Supply and sale agricultural machinery and } \\
\text { institutions }\end{array}$ & 3.40 & 0.83 & 10.75 & Applicable & 3 \\
\hline & $\begin{array}{c}\text { Creation contracting and engineering services } \\
\text { companies in the fields of technical and } \\
\text { Infrastructure affairs }\end{array}$ & 3.25 & 0.60 & 10.47 & Applicable & 5 \\
\hline
\end{tabular}


The results of confirmative factorial analysis show that just three items of factorial load and significance coefficients had been confirmed. According to this fact that average of 7 plans from 8 ones are higher than 3 and all the factorial loads and significance coefficients have been confirmed, so among identified plans in the field of productive cooperatives, 7 plans are applicable. Prioritizing plans has been done according to average upon which three plans including study, design and implementation of pressurized irrigation systems, Hydrology and geology laboratories establishment and Supply and sale agricultural machinery and institutions are respectively placed at first, second and third rank of priority.

\subsection{Confirmative factorial analysis of small opportunities plans}

5 number of suggested plans in classification of small opportunities plans were identified that mean and confirmative factorial analyses have been used for applicability, importance and prioritizing these plans whose results have been reported in continue.

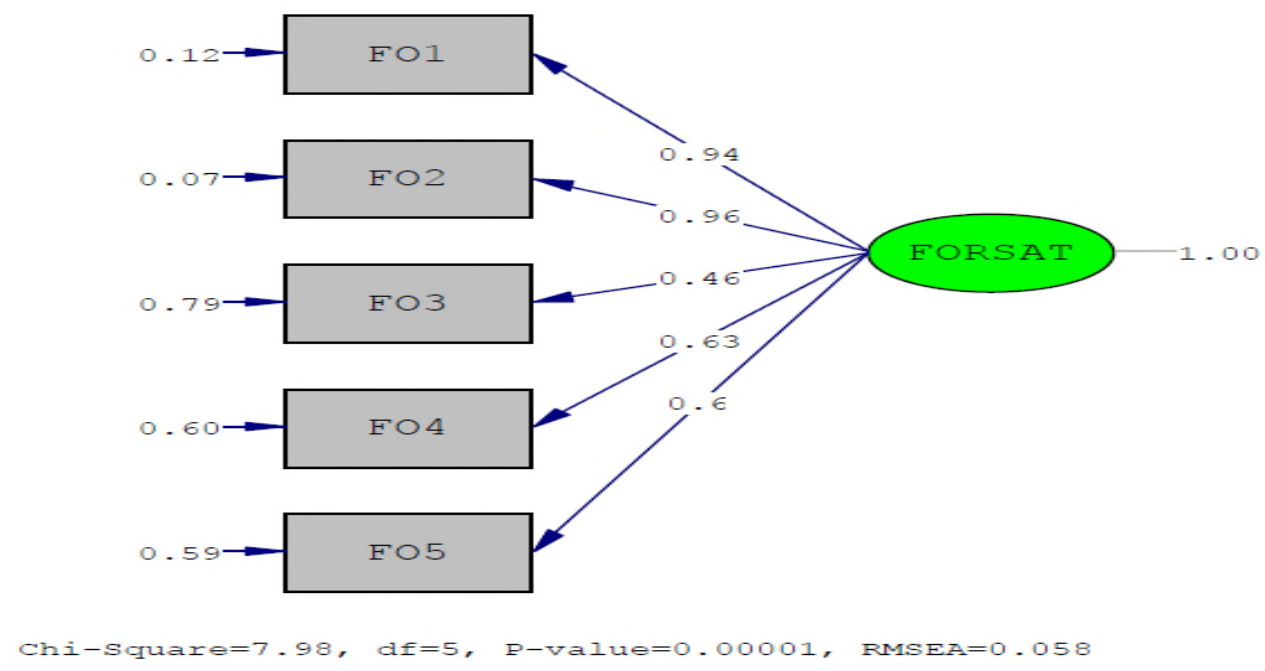

Diagram 9: Confirmative factorial analysis of small opportunities plans at standard estimation status

Table 10: The results of confirmative factorial analysis

\begin{tabular}{|c|c|c|c|c|c|c|}
\hline $\begin{array}{l}\text { Category of } \\
\text { plans }\end{array}$ & Identified plans & mean & $\begin{array}{c}\text { Factorial } \\
\text { load }\end{array}$ & $\begin{array}{l}\text { Significance } \\
\text { number }\end{array}$ & Result & prioritizing \\
\hline \multirow{5}{*}{ 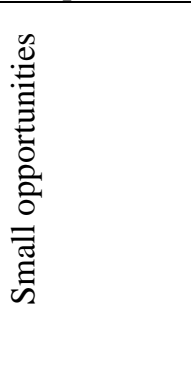 } & $\begin{array}{l}\text { Feed production (harvest and production of } \\
\text { forage plants }\end{array}$ & 3.32 & 0.94 & 13.06 & Applicable & 1 \\
\hline & $\begin{array}{l}\text { Seeds production base and agricultural seeds } \\
\text { production }\end{array}$ & 3.30 & 0.96 & 13.15 & Applicable & 2 \\
\hline & Industrial milk industry & 2.34 & 0.46 & 1.45 & $\begin{array}{l}\text { Non- } \\
\text { applicable }\end{array}$ & \\
\hline & $\begin{array}{l}\text { Production of livestock and poultry feed and } \\
\text { seed Sifter station (fixed-mobile) }\end{array}$ & 3.01 & 0.63 & 9.35 & Applicable & 3 \\
\hline & Production of fodder & 2.86 & 0.6 & 9.15 & Applicable & \\
\hline
\end{tabular}

The results of confirmative factorial analysis show that just three items of factorial load and significance coefficients had been confirmed. According to this fact that average of 3 
plans from 5 ones are higher than 3 and all the factorial loads and significance coefficients have been confirmed, so among identified plans in the field of productive cooperatives, 3 plans are applicable. Prioritizing plans has been done according to average upon which three plans including feed production (harvest and production of forage plants, seeds production base and agricultural seeds production and production of livestock and poultry feed and seed Sifter station (fixed-mobile) are respectively placed at first, second and third rank of priority.

\section{Research's result}

The result of research's statistical analysis has been very pivotal according to pollution load and risks for environment and respecting application of full collection of experts concerned and involved in the sidelines of these developmental plans approval in province in recent year and it can be used as an appropriate reference for rejecting or approving above plans in the basin of Ilam's drinking water dam. In addition, according to priority of research type, research's general features can be used in similar researches for other country's dams which are applied as drinking water resource. Research's total result has been summarized in below table:

Table 11: research's final results

\begin{tabular}{|c|c|c|c|}
\hline Classification of plans & Number of suggested plan & applicable & Non-applicable \\
\hline Plant production & 9 & 9 & - \\
\hline Livestock production & 3 & 3 & - \\
\hline Water, soil and industry & 21 & 3 & 18 \\
\hline Veterinary & 8 & 3 & 5 \\
\hline Jungle, rangeland and watershed & 10 & 10 & - \\
\hline Promotion and exploitation & 5 & 5 & - \\
\hline Economic organization & 13 & 13 & - \\
\hline Productive cooperation & 8 & 7 & 1 \\
\hline Job opportunities & 5 & 4 & 1 \\
\hline
\end{tabular}

According to classification of plans, plants production plans in 9 groups and livestock production in 3 groups had been totally applicable and just three plans of soil, water and industry plans which were studies in 21 groups have been applicable including wood products industry and manufacture of food products including cookies and pastry industry and production of bricks and ready concrete products plan. In veterinary plans classification, 3 of 10 groups including establishment of convertible and complementary industry subdivision of livestock production, fridge, Processing and packaging of meat, poultry and dairy products, establishment of convertible and complementary industry subdivision of fishery including processing, freezing and packing different types of fish, shrimp and conserves and breeding hydrothermal and cold-water fish with factorial load higher than 93 and 60 percent which indicate necessity of some measures regarding implementation, have been applicable. All the groups in jungle, rangeland and watershed plans which have been divided into 10 groups were applicable. All groups in promotion and exploitation plans including 5 groups have been also confirmed. All 13 cases in economic organization plans have been applicable. From 8 plans of cooperative production 
plans, just fight against pests and plant diseases plan have had low factorial load and it has not been applicable. From 5 plans of job opportunities plans, industrial milk industry has not been applicable.

\section{References}

[1] Ahmadi. Ali, Hajinezhad, Ali (2010). Environment degradation obstacle against sustainable development, Researches of the fourth International Congress of Islamic World Geoghraphers, zahedan, 25 to 27 Farvardin.

[2] Tohidinia, Abolghasem (1383). Morality, Economic \& Environment, Economic Essays Journal,1(2) p.157-176.

[3] Habibi, Bastami,Valiollah, Afshari, Hoshang.(1388).Water, agricultural development and employment in Border areas of the country, Proceedings of the Conference on, Agriculture \& National Development.

[4] Dizji, Manizheh, Ghlaminezhad Digareh, Solmaz. (1390).Economic Growth, Human development\& Water pollution caused by economic activity in selected countries of the world, Journal of APPLIED Economics, 3th year, N.11

[5] Shaibani, Behzad (1392). Environmental Impact Assessmentin irrig tion and drainage networks. The first National Conference on water resources and agricultural challenges, Iran Irrigation \& Drinage Committee, Islamic Azad University of Isfahan, Khorasgan Branch.

[6] Farhadian, Mozhgan, Kianoosh, Vahed (1393). Environmental, social \& economical impact assessment by Matrix method with emohasis on water resources management. Case study: Nahavand Green Dam ( International Journal of Analytical researches on water resources and development, second year, N.1

[7] Ghaderi, Abasali (1383). Investigating plants role in natural refining of urban polluted waters. Case study: Tehran polluted waters refining by constructed wetland. Scientific Journal of Geography and development, zahedan, 2th year, n.3, p.107-120.

[8] Karamooz, Mohammad, Eliasi, Asghar, Ahmadinia, Saleh. (1387).Facilitating economically the effects of demand management policies in water resources development plans, Case study : Journal Civil Engineering of Islamic Azad University, 1TH YEaR,n.2

[9] Kiani Haftleng, Kianoosh (1384).Human Ecology, Tehran, Paniz Press.

[10] Gerasimov et al. (1372).Human, society \& environment, Translated by Salahal-Din Mahalati, Tehran, Shahid Beheshti University Press 